\title{
The Impacts of Interest Rate and Exchange Rate Volatilities on the Demand for Money in Developing Economies
}

\author{
Felix S. Nyumuah ${ }^{1}$ \\ ${ }^{1}$ Department of Financial Management, Zenith University College, Accra, Ghana \\ Correspondence: Felix S. Nyumuah, P.O. Box SK 237, Sakumono Estates, Tema, Ghana. Tel: 233-243-671-295. \\ E-mail: fsnyumuah@yahoo.co.uk or silverglw7@gmail.com
}

Received: January 19, 2017

Accepted: February 14, $2017 \quad$ Online Published: January 30, 2018

doi:10.5539/ijef.v10n3p56

URL: https://doi.org/10.5539/ijef.v10n3p56

\begin{abstract}
Volatilities in the interest rate and the exchange rate cause instability in money demand functions. This study investigates the effect of interest and exchange rates volatilities on money demand in developing countries using time series data of four African countries namely, Equatorial Guinea, Gambia, Nigeria and Uganda. The model used is a conventional log linear money demand function, with money demand specified as a function of income, interest rate, inflation rate, exchange rate, interest rate volatility and exchange rate volatility. The results show that on the whole the interest rate and exchange rate volatilities do not have significant effects on money demand in developing countries. However, the money demand functions of these economies prove unstable. These findings imply that the monetary authorities should resort to inflation targeting monetary policy and employ the interest rate as the policy instrument.
\end{abstract}

Keywords: demand for money, money demand stability, interest rate volatility, exchange rate volatility, monetary policy

\section{Introduction}

Issues which have been investigated concerning the demand for money are the correct opportunity cost variable to enter the money demand function and the stability of the function. The important determinants of money demand of an economy are often known to be the interest rate and the level of economic activity. According to Fleming (1962) policy-makers had considered only the closed economy in the formulating of monetary policy, but with the worldwide trade of goods and services there was the need to look at the open economy. He identified the exchange rate as being an important variable in money demand functions for open economies in addition to income and the interest rate. Uncertainty or volatility in exchange rates could affect the amount of cash balances being held by economic agents. For example, an adverse exchange rate, in the form of volatility will cause economic agents to substitute the domestic currency for foreign currency, thus reducing the demand for money balances. Economic theory indicates that interest rate volatility also increases the demand for money. Any factor that positively affects the demand for money can adversely affect the economy through its negative effect on nominal income (Celikoz \& Arslan, 2011).

A large body of literature exists concerning examining the effect of the interest rate volatility or the exchange rate volatility on money demand. Celikoz and Arslan (2011) studied the relationship between the interest rate volatility and the demand for money for Turkey. Their study showed that the interest rate volatility was not statistically significant and had a positive relationship with the demand for money. Githinji (2015) conducted a study with the main objective of evaluating the impact of interest rate volatility on money demand in Kenya. Ordinary Least Squares (OLS) method was employed as an estimation technique. The results showed that the volatility of the interest rate was statistically significant in determining money demand in Kenya. Further, the volatility of the interest rate was found to be negatively related to money demand in Kenya.

In a study of the demand for money in Pakistan, Qasim, Ahmad, and Chani (2015) find the exchange rate volatility to have a significant negative effect on the demand for money in the long run. Sahar (2013) employs the bounds testing technique and with annual data from 15 developing countries, demonstrates that exchange rate volatility has short-run effects on the demand for real money balances in developing economies.

Interest rate and exchange rate volatilities or uncertainties could cause money demand functions to be unstable. A 
good understanding of the relationship between money demand and its determinants is fundamental in choosing the proper monetary policy instrument in guiding the economy (Gaurisankar \& Kwie-Jurgens, 2013). According to the monetarists, the supply of money is a key policy variable in stabilising an economy. To them, lags and uncertainties render discretionary monetary policy ineffective in economic stabilisation. The best way out for the government is to ensure a steady increase of the money supply in line with the increase in money income. According to the monetarists, a stable money demand function will ensure predictability of the influence of money supply on the growth of money income. The monetarists believe that a stable money demand function means a stable money multiplier. This will ensure that reserve money becomes controllable and the money stock predictable (Gaurisankar \& Kwie-Jurgens, 2013). The stability of money demand functions has implications for the choice of monetary policy instruments. Poole (1970) argues that central banks should target money supply when money demand is stable and interest rate when the relationship is unstable. Using the inappropriate instrument will only accentuate instability. Despite the fact that interest rate and exchange rate volatilities could trigger instability in the money demand functions, these issues have been rarely investigated in developing economies as compared to the advanced ones. Moreover, most studies have had as their main objective to either examine the effect of the interest rate volatility or the exchange rate volatility but not the effects of both simultaneously. In this regard, this study investigates the effect of interest and exchange rates volatilities on the demand for money in developing economies using time series data of four African countries namely, Equatorial Guinea, Gambia, Nigeria and Uganda. All the four countries are typical developing sub-Saharan African countries. Nigeria relies heavily on a single product, that is oil, for exports but the Gambia is relatively diversified in her export products with a relatively low share of the primary sectors. (Benassy-Quere \& Coupet, 2005). The Nigerian economy is therefore highly vulnerable to shocks in world oil prices. In the early1990s, all the countries had per capita Gross National Income (GNI) below US\$546 indicating that they were low income countries (Appendix 3). The economy of Equatorial Guinea saw a dramatic growth following the discovery of oil in 1996 with the per capita GNI ranging between US\$7,180 and US\$14,130 from 2008 to 2016 and thus becoming an upper middle income country. Even though the Nigerian economy did not grow as much as that of Equatorial Guinea, it moved into the lower middle income countries bracket over the period. The other two countries, however, remained low income countries (Appendix 3). This study will contribute immensely to the literature, in that this is the first time both the interest rate and exchange rate volatilities variables are included simultaneously in the money demand function for developing economies, in addition to the traditional determinants of money demand.

The main aim of this paper is to look at three questions: Does volatility in the interest rate influence significantly the demand for money? Does volatility in exchange rates have an impact on cash balances agents are willing to hold? Is the demand for money stable in an open developing country? These questions have important policy implications for all developing countries across the world.

With the objective of the study in mind, the rest of the study proceeds with Section 2 describing the theoretical underpinnings. The data and econometric framework on which the study is based are described in Section 3 . Section 4 presents the empirical results while Section 5 ends the study with concluding remarks.

\section{Theoretical Frameworks}

\subsection{The Relationship between Interest Rate Volatility and Money Demand}

The asset and transactions demand theories of money indicate that high level of uncertainty in interest rates might increase the desired monetary balances held by businesses and households. A rise in the volatility or uncertainty of interest rates increases the risk of maintaining fixed-income securities. Businesses and households would therefore like to keep more cash balances in order to decrease this risk.

The portfolio theory of money demand captures interest rate uncertainty into the theory of demand for money. This theory proposes that the demand for money would increase with greater interest rate uncertainty. Even though money attracts less interest than other assets, it is a preferable asset in financial portfolios because it is less risky as compared to the other assets. Money is different from bonds in that the value of money remains constant with fluctuations in interest rates. Greater uncertainty about interest rates would cause risk-averse investors to increase their asset demand for money.

The transactions demand for money also increases as interest rate volatility increases. The transactions motive of holding money stresses the medium of exchange role of money. Businesses and households must have cash balances to buy and sell goods and services. The amount of money held for transactions varies directly with the overall level of transactions and inversely with the interest rate on securities. The standard model of the transactions demand for money has been revised currently to show how greater interest rate uncertainty could 
lead to larger risk-free cash balances being held. For the same reason, interest rate uncertainty increases both the transactions demand and the asset demand for money. There is an increased motivation to hold money as the risk of holding alternative assets rises. Therefore, it can be concluded that there is a positive relationship between the demand for money and the volatility of the interest rate.

Higher volatility of interest rates would have far-reaching macroeconomic implications if interest rate volatility really affects money demand. Greater uncertainty in interest rates would increase the average level of interest rates through increasing money demand. Interest rates variations will make long-term assets less attractive because of the greater risk of price fluctuations. Consequently, uncertainty in the interest rate could increase long-term interest rates.

The higher average level of long-term interest rates could reduce real output and employment in a variety of ways. Higher long-term interest rates depress fixed asset investments by businesses, housing construction and consumer spending. Furthermore, under a system of flexible exchange rates, higher interest rates are also likely to attract foreign capital inflows, which could cause the domestic currency to appreciate. A stronger domestic currency lessens real economic activity by decreasing exports and reducing production in import-competing industries.Higher interest rate volatility could also slow down the velocity of money. From the equation of exchange, the velocity of money is equal to the nominal Gross National Product (GNP) divided by the quantity of money in circulation. Velocity would decline if interest rate volatility were to raise the desired money balances.

The impact of interest rate volatility on money demand is important in the formulation of monetary policy. Policymakers might set monetary growth targets based on the expected behaviour of velocity in the following year. Let us assume that the monetary authorities of a country estimate that 2 to 4 percent money growth would be compatible with the desired economic performance. An unexpected rise in money demand and thus an unexpected reduction in velocity may necessitate faster monetary growth, for example 4 to 6 percent to achieve the desired economic results. Monetary policy will fail if these developments are ignored.

\subsection{Effect of Exchange Rate Volatility on Money Demand}

Economists have made some efforts to modify the conventional money demand specification of the closed economy to incorporate the effect of the exchange rate. The idea to account for the exchange rate as another important determinant of money demand was proposed by Mundell (1963). He added the exchange rate to income and the rate of interest in the money demand specification. The importance of exchange rates is also emphasised by Izadi and Dehmarde (2012), Sameti and Mehdi (2011) and Dehmarde and Izadi (2009).

Exchange rate volatility is the persistent variabilities of the exchange rate. This uncertainty in the exchange rate has dual effects on the demand for the domestic currency, the wealth effect and the currency substitution effect. Supposing the domestic currency serves as the terms in which wealth holders value their asset portfolios, the depreciation of the exchange rate would increase the value of their foreign assets and thus make them wealthier. They will transfer part of their foreign assets into domestic assets, including the domestic currency, in order to keep a fixed share of their wealth invested in domestic assets. The demand for the domestic currency will thus increase as a result of exchange rate depreciation.

Alternatively, movements in the exchange rate can produce a currency substitution effect with investors' expectations being critical. If the owners of wealth develop an expectation that there will be a further decrease in the exchange rate after an initial decline, they will react by increasing the proportion of foreign assets in the portfolio. Thus, exchange rate depreciation would reduce the demand for the domestic currency. Advocates of the argument that foreign currency is substitutable for domestic currency have pointed out certain evidence. It is argued that, various economic agents attempt to diversify their portfolios by holding various currencies at the same time in order to reduce the costs and risks associated with foreign transactions (Miles, 1978). Individuals will thus react to changes in the cost of holding one currency in relation to another by changing the relative amount of each currency held. Whether the relationship between demand for money and exchange rate volatility is positive or negative will depend on the magnitudes of the wealth and currency substitution effects. The relationship will be positive if the wealth effect outweighs the substitution effect and negative when the substitution effect dominates the wealth effect.

\section{Data and Econometric Framework}

This study investigates the effects of interest rate variability and exchange rate variability on the money demand function of developing economies. The analytical tools employed comprise unit root test, vector error correction test, the Ordinary Least Squares regression and the CUSUM and CUSUMSQ tests. The econometric software 
Eviews is used to obtain regression estimates and to carry out the tests. The data for the study is annual data obtained from World Bank Development Indicators 2003 covering the sample period 1993 to 2012. 80 quarterly data points are generated from the sample by converting low frequency data to high frequency data in EViews using the constant-match average method.

Conventionally, the demand for money has been specified as a function of a scale variable such as national income and the opportunity cost of holding money such as the interest rate or the rate of inflation. With economies now engaging in international trade, the exchange rate is incorporated to cater for currency substitution. I include both the interest rate and inflation rate variables since Arestis and Demetriades (1991) argue for the inclusion of both variables because the expected rate of inflation serves as the return on real assets while the nominal interest rate represents own-rate of money. Volatility measures for the interest rate and the exchange rate are added, and the long-run money demand function used to assess the effects of the interest rate and exchange rate volatilities on the demand for money is specified as follows:

$$
m_{t}=\beta_{0}+\beta_{1} y_{t}+\beta_{2} i_{t}+\beta_{3} \Pi_{t}+\beta_{4} e r_{t}+\beta_{5} V i_{t}+\beta_{6} V_{e r}+u_{t}
$$

where $\mathrm{m}_{\mathrm{t}}$ is the natural logarithm of real money balances held measured by the narrow definition M1. The Consumer Price Index (CPI) is the deflator used to obtain real money balances and real Gross Domestic Product (GDP). The variables, $y_{t}, i_{t}$ and $\Pi_{t}$ represent the natural logarithms of real GDP, the interest rate and the inflation rate respectively. The volatility measures of the interest rate and exchange rate are denoted by $\mathrm{Vi}_{\mathrm{t}}$ and $\mathrm{Ver}_{\mathrm{t}}$ respectively. The $\beta_{\mathrm{S}}$ are the coefficients to be estimated while $\mathrm{u}_{\mathrm{t}}$ represents the error term. From the theoretical perspective, the real GDP and the interest rate volatility are expected to be positively related to the demand for money. The interest rate and the inflation rate are expected to exert a negative influence on money demand. The exchange rate and the exchange rate volatility could have a negative or positive influence on the demand for money depending on whether the wealth effect or the currency substitution effect dominates. The CPI serves as a proxy for the inflation rate. Volatility measures are obtained from the four-quarter moving standard deviations of the interest and exchange rates.

I use the augmented Dickey-Fuller (ADF) test to check for the presence of unit roots. This is to ascertain the stationarity properties of the time series in order to avoid spurious regression or random walk. A time series which is non-stationary follows a random walk and requires first-differencing to obtain stationarity, and is said to be integrated of order one, that is, I(1). A variable that is stationary in level form is integrated of order zero, that is, $\mathrm{I}(0)$. The standard $\mathrm{ADF}$ test is based on the model

$$
Y_{t}=\beta_{1}+\beta_{2} Y_{t-1}+\gamma t+u_{t}
$$

which is rewritten as

$$
\Delta Y_{t}=\beta_{1}+\left(\beta_{2}-1\right) Y t_{-1}+\gamma t+u_{t}
$$

where $\Delta \mathrm{Y}_{\mathrm{t}}=\mathrm{Y}_{\mathrm{t}}-\mathrm{Y}_{\mathrm{t}-1}$. The null hypothesis for stationarity is $\mathrm{H}_{0}: \beta_{2}-1=0$ and the alternative hypothesis is $\mathrm{H}_{1}$ : $\beta_{2}-1 \neq 0$. One cannot use the standard t-test method because the distribution of the $t$-statistic is not a t-distribution, so the finite sample critical values and p-values for the ADF test developed by MacKinnon (1996) are used to determine statistical significance.

A pair of I(1) time series are said to be cointegrated if some linear combination of them is stationary. A cointegration test is used to determine whether or not a stable long-run relationship exists among a set of variables. If there is cointegration between the monetary aggregate and the determinants of money demand their linear combination $\varepsilon_{\mathrm{t}}=\mathrm{m}_{\mathrm{t}}-\alpha_{0}-\alpha_{1} \mathrm{y}_{\mathrm{t}}-\alpha_{2} \mathrm{i}_{\mathrm{t}}-\alpha_{3} \Pi_{\mathrm{t}}$ should be $\mathrm{I}(0)$. To test for cointegration among the variables the residual of the estimated OLS model is tested for stationarity. There is cointegration among the variables if the residual is stationary.

Engle and Granger (1987) showed that the existence of cointegration among nonstationary variables means the data can be validly represented by an error correction model. To derive the error correction model (ECM) I consider a simple $\operatorname{ADL}(1,1)$ model.

$$
m_{t}=\alpha_{1}+\alpha_{2} m_{t-1}+\alpha_{3} y_{t}+\alpha_{4} y_{t-1}+\alpha_{5} i_{t}+\alpha_{6} i_{t-1}+\alpha_{7} \Pi_{t}+\alpha_{8} \Pi_{t-1}+\alpha_{9} e r_{t}+\alpha_{10} e r_{t-1}+\alpha_{11} V i_{t}+\alpha_{12} V i_{t-1}+\alpha_{13} V e r_{t}+\alpha_{14} V e r_{t-1}+u_{t}
$$

where $\mathrm{m}_{\mathrm{t}}, \mathrm{y}_{\mathrm{t}}, \mathrm{i}_{\mathrm{t}}, \Pi_{\mathrm{t}}, \mathrm{er}_{\mathrm{t}}, \mathrm{Vi}_{\mathrm{t}}$ and $\operatorname{Ver}_{\mathrm{t}}$ are $\mathrm{I}(1)$.

Rewrite (4) as

$$
\begin{aligned}
m_{t}-m_{t-1}=\alpha_{1}+\alpha_{2} m_{t-1}-m_{t-1}+\alpha_{3} y_{t}-\alpha_{3} y_{t-1}+\alpha_{3} y_{t-1}+\alpha_{4} y_{t-1}+\alpha_{5} i_{t}-\alpha_{5} i_{t-1}+\alpha_{5} i_{t-1}+\alpha_{6} i_{t-1}+\alpha_{7} \Pi_{t}-\alpha_{7} \Pi_{t-1}+ \\
\alpha_{7} \Pi_{t-1}+\alpha_{8} \Pi_{t-1}+\alpha_{9} e r_{t}-\alpha_{9} e r_{t-1}+\alpha_{9} e r_{t-1}+\alpha_{10} e r_{t-1}+\alpha_{11} V_{t^{-}} \alpha_{11} V i_{t-1}+\alpha_{11} V i_{t-1}+\alpha_{12} \operatorname{Vit}_{t-1}+\alpha_{13} \operatorname{Ver}_{t}-\alpha_{13} \operatorname{Ver}_{t-1}+\alpha_{13} \operatorname{Ver}_{t-1}+ \\
\alpha_{14} \operatorname{Ver}_{t-1}+u_{t}
\end{aligned}
$$




$$
\begin{aligned}
& \Delta m_{t}=\alpha_{1}-\left(1-\alpha_{2}\right) m_{t-1}+\alpha_{3} \Delta y_{t}+\left(\alpha_{3}+\alpha_{4}\right) y_{t-1}+\alpha_{5} \Delta i_{t}+\left(\alpha_{5}+\alpha_{6}\right) i_{t-1}+\alpha_{7} \Delta \Pi_{t}+\left(\alpha_{7}+\alpha_{8}\right) \Pi_{t-1}+\alpha_{9} \Delta e r_{t}+ \\
& \left(\alpha_{9}+\alpha_{10}\right) e r_{t-1}+\alpha_{11} \Delta V i_{t}+\left(\alpha_{11}+\alpha_{12}\right) V i_{t-1}+\alpha_{13} \Delta V e r_{t}+\left(\alpha_{13}+\alpha_{14}\right) V e r_{t-1}+u_{t} \\
& \Delta m_{t}=\alpha_{3} \Delta y_{t}+\alpha_{5} \Delta i_{t}+\alpha_{7} \Delta \Pi_{t}+\alpha_{9} \Delta e r_{t}+\alpha_{11} \Delta V i_{t}+\alpha_{13} \Delta V e r_{t}-\left(1-\alpha_{2}\right)\left[m_{t-1}-\left(\alpha_{1} / 1-\alpha_{2}\right)-\left(\alpha_{3}+\alpha_{4}\right) y_{t-1} /\left(1-\alpha_{2}\right)-\left(\alpha_{5}+\alpha_{6}\right) i_{t-1}\right. \\
& \left./\left(1-\alpha_{2}\right)-\left(\alpha_{7}+\alpha_{8}\right) \Pi_{t-1} /\left(1-\alpha_{2}\right)-\left(\alpha_{9}+\alpha_{10}\right) e r_{t-1} /\left(1-\alpha_{2}\right)-\left(\alpha_{11}+\alpha_{12}\right) V i_{t-1} /\left(1-\alpha_{2}\right)-\left(\alpha_{13}+\alpha_{14}\right) \operatorname{Ver}_{t-1} /\left(1-\alpha_{2}\right)\right]+u_{t} \\
& \Delta m_{t}=\alpha_{3} \Delta y_{t}+\alpha_{5} \Delta i_{t}+\alpha_{7} \Delta \Pi_{t}+\alpha_{9} \Delta e r_{t}+\alpha_{11} \Delta V i_{t}+\alpha_{13} \Delta V e r_{t}-\lambda\left[m_{t-1}-\beta_{1}-\beta_{2} y_{t-1}-\beta_{3} i_{t-1}-\beta_{4} \Pi_{t-1}-\beta_{5} e r_{t-1}-\beta_{6} V i_{t-1}-\right. \\
& \left.\beta_{7} \operatorname{Ver}_{t-1}\right]+u_{t}
\end{aligned}
$$

where

$$
\begin{gathered}
\lambda=\left(1-\alpha_{2}\right) ; \beta_{1}=\alpha_{1} /\left(1-\alpha_{2}\right) ; \beta_{2}=\left(\alpha_{3}+\alpha_{4}\right) /\left(1-\alpha_{2}\right) ; \beta_{3}=\left(\alpha_{5}+\alpha_{6}\right) /\left(1-\alpha_{2}\right) ; \beta_{4}=\left(\alpha_{7}+\alpha_{8}\right) /\left(1-\alpha_{2}\right) \beta_{5}=\left(\alpha_{9}+\alpha_{10}\right) /\left(1-\alpha_{2}\right) ; \beta_{6}= \\
\left(\alpha_{11}+\alpha_{12}\right) /\left(1-\alpha_{2}\right) \text { and } \beta_{7}=\left(\alpha_{13}+\alpha_{14}\right) /\left(1-\alpha_{2}\right)
\end{gathered}
$$

Equation (5) is the ECM which can be rewritten as:

$$
\Delta m_{t}=\alpha_{3} \Delta y_{t}+\alpha_{5} \Delta i_{t}+\alpha_{7} \Delta \Pi_{t}+\alpha_{9} \Delta e r_{t}+\alpha_{11} \Delta V i_{t}+\alpha_{13} \Delta V e r_{t}-\lambda u_{t-1}
$$

When the variables $\mathrm{m}, \mathrm{y}, \mathrm{i}, \Pi$, er, Vi and Ver are cointegrated, the ECM incorporates not only the short-run but also long-run effects. The long run equilibrium $\mathrm{m}_{\mathrm{t}-1}-\beta_{1}-\beta_{2} \mathrm{yt}_{-1}-\beta_{3} \mathrm{i}_{\mathrm{t}-1}-\beta_{4} \Pi_{\mathrm{t}-1}-\beta_{5} \mathrm{er}_{\mathrm{t}-1}-\beta_{6} \mathrm{Vi}_{\mathrm{t}-1}-\beta_{7} \mathrm{Ver}_{\mathrm{t}-1}$ is included in the model together with the short-run effects captured by the differenced terms.

The coefficient $\lambda$ provides us with the information about the speed of adjustment to equilibrium. If $\lambda=1$, then full adjustment takes place within the period, that is adjustment is instantaneous. If $\lambda=0.5$, then $50 \%$ adjustment takes place each period and if $\lambda=0$, then there is no adjustment.

To model the effects of volatilities of the interest rate and the exchange rate on the money demand function, equation (6) the error correction model is used to capture the short run adjustment mechanism while equation (1) is used to represent the long run money demand function. Equations (1) and (6) are estimated using the Ordinary Least Squares (OLS) method to examine the short-run and long run effects of the interest rate and exchange rate volatilities. To avoid the problem of spurious regression the stationarity properties of the time series are ascertained by conducting unit root tests. Cointegration among the relevant variables is also tested for to establish a long run equilibrium relationship between them. Once cointegration is established, the CUSUM and CUSUMSQ tests are applied to the residuals of Equation (1). These tests are based on the cumulative sum of recursive residuals and the squared recursive residuals. They are updated recursively and are plotted against the break points. If the plots stay within a 5 percent significance level (shown by two straight lines), then the coefficient estimates are said to be stable.

As a robustness check, I follow Pesaran, Shin, and Smith's (2001) bounds testing method, and use the following error-correction specification:

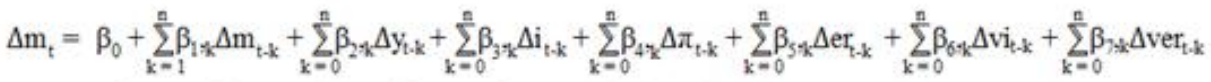

$$
\begin{aligned}
& +\delta_{1} \mathrm{~m}_{t-1}+\delta_{2} \mathrm{y}_{t-1}+\delta_{3} \mathrm{i}_{\mathrm{t}-1}+\delta_{4} \pi_{t-1}+\delta_{\mathrm{get} t-1}+\delta_{6} \mathrm{vi}_{t-1}+\delta_{7} \mathrm{ver}_{t-1}+\mu_{t}
\end{aligned}
$$

Pesaran et al. (2001) suggest estimating equation (7) by OLS method. The dynamics of the model is ascertained by imposing different lags on the first differenced variables up to a maximum of eight lags. Thereafter the Akaike Information Criterion (AIC) is used to select the optimum number of lags for the model. After the estimation, an $\mathrm{F}$ test is carried out to determine the joint significance of lagged level variables as a sign of cointegration. Pesaran et al. (2001) have tabulated the critical values for this F test. There is cointegration if the calculated $\mathrm{F}$ statistic is greater than the upper bound critical value. If co-integration is rejected among the variables by the $F$ test, the lagged error term $\varepsilon_{t-1}$ from equation (1) is used to replace the lagged level variables to form an error correction term. Equation (7) is re-estimated after replacing the lagged level variables by $\varepsilon_{\mathrm{t}-1}$. A negative and significant coefficient obtained for $\varepsilon_{t-1}$ means the variables in the money demand function are co-integrated and converge towards their long-run equilibrium values. The CUSUM and CUSUMSQ tests are applied to the residuals of Equation (7) once there is cointegration among the variables. Equation (7) incorporates both short-run effects and long-run effects. The short-run effects are determined from the estimate of coefficients of all first-differenced variables while the long-run effects are derived from the estimates of $\delta_{2 \ldots} \delta_{7}$ that are normalized on $\delta_{1}$.

\section{The Results}

\section{1 Baseline Results}

Table 1 reports the results of the Augmented Dickey- Fuller(ADF) unit root test performed for the variables. 
Table 1. Unit root tests results for order of integration of the variables (ADF)

\begin{tabular}{|c|c|c|c|c|}
\hline Variable & Equatorial Guinea & Gambia & Uganda & Nigeria \\
\hline \multicolumn{5}{|l|}{$\mathbf{m}$} \\
\hline \multirow[t]{2}{*}{ At Level } & -1.92309 & 2.916445 & -0.94558 & -4.39762 \\
\hline & $(0.6328)$ & $(0.1633)$ & $(0.9447)$ & $(0.0039)$ \\
\hline \multirow[t]{2}{*}{ First Difference } & -4.55865 & -2.121113 & -3.0222 & -2.60754 \\
\hline & $(0.0024)$ & $(0.5257)$ & $(0.1331)$ & $(0.2783)$ \\
\hline \multicolumn{5}{|l|}{$\mathbf{y}$} \\
\hline \multirow[t]{2}{*}{ At Level } & -0.2322 & -3.664608 & -3.82922 & -1.22593 \\
\hline & $(0.9912)$ & $(0.0309)$ & $(0.0201)$ & $(0.8977)$ \\
\hline \multirow{2}{*}{ First Difference } & -3.16326 & -4.396944 & -5.07774 & -5.68339 \\
\hline & $(0.0997)$ & $(0.0041)$ & $(0.0005)$ & $(0.0001)$ \\
\hline \multicolumn{5}{|l|}{$\mathbf{i}$} \\
\hline \multirow[t]{2}{*}{ At Level } & -3.72328 & -1.488926 & -1.63789 & -3.64428 \\
\hline & $(0.0266)$ & $(0.8246)$ & $(0.7686)$ & $(0.0325)$ \\
\hline \multirow[t]{2}{*}{ First Difference } & -3.36456 & -2.75855 & -4.01108 & -4.62291 \\
\hline & $(0.064)$ & $(0.2173)$ & $(0.0123)$ & $(0.0019)$ \\
\hline \multicolumn{5}{|l|}{$\pi$} \\
\hline \multirow[t]{2}{*}{ At Level } & -4.89988 & -3.338234 & -0.25014 & -5.88048 \\
\hline & $(0.0008)$ & $(0.0678)$ & $(0.9907)$ & $(0.0000)$ \\
\hline \multirow[t]{2}{*}{ First Difference } & -3.96899 & -2.197827 & -1.27771 & -5.99052 \\
\hline & $(0.014)$ & $(0.4837)$ & $(0.8855)$ & $(0.0000)$ \\
\hline \multicolumn{5}{|l|}{ er } \\
\hline \multirow[t]{2}{*}{ At Level } & -3.37027 & -2.400214 & -0.97703 & -1.9034 \\
\hline & $(0.063)$ & $(0.3765)$ & $(0.9404)$ & $(0.6429)$ \\
\hline \multirow[t]{2}{*}{ First Difference } & -2.55483 & -2.544898 & -1.85603 & -2.69414 \\
\hline & $(0.3019)$ & $(0.3064)$ & $(0.6668)$ & $(0.2421)$ \\
\hline \multicolumn{5}{|l|}{$\mathbf{V i}$} \\
\hline \multirow[t]{2}{*}{ At Level } & -2.09493 & -1.784606 & -3.49369 & -4.98373 \\
\hline & $(0.5403)$ & $(0.7028)$ & $(0.0469)$ & $(0.0006)$ \\
\hline \multirow[t]{2}{*}{ First Difference } & -3.83576 & -5.425476 & -7.07263 & -7.18291 \\
\hline & $(0.0197)$ & $(0.0001)$ & $(0.0000)$ & $(0.0000)$ \\
\hline \multicolumn{5}{|l|}{ Ver } \\
\hline \multirow[t]{2}{*}{ At Level } & -5.20549 & -3.540432 & -4.11791 & -2.89931 \\
\hline & $(0.0003)$ & $(0.0419)$ & $(0.0089)$ & $(0.1684)$ \\
\hline \multirow[t]{2}{*}{ First Difference } & -7.4286 & -5.71635 & -6.51081 & -7.3719 \\
\hline & $(0.0000)$ & $(0.0000)$ & $(0.0000)$ & $(0.0000)$ \\
\hline \multicolumn{5}{|l|}{$\mathbf{U}$} \\
\hline \multirow[t]{2}{*}{ At Level } & -3.49568 & -3.382458 & -2.45197 & -3.12998 \\
\hline & $(0.047)$ & $(0.0613)$ & $(0.3507)$ & $(0.1069)$ \\
\hline
\end{tabular}

Note. The critical and probability values were obtained from EViews using the Schwarz Information Criteria. The probability values are shown in the brackets.

According to the results, not all the variables are integrated of order one, I(1). Of all the seven variables (real money balances, real GDP, the domestic interest rate, the inflation rate, the interest rate volatility and the exchange rate volatility) for the four countries, the real money balances variable is I(1) for only Equatorial Guinea and the interest rate variable is I(1) for only Uganda at the 5\% level of significance. The interest rate volatility variable is I(1) for Equatorial Guinea and Gambia whilst the real GDP and exchange rate volatility variables become stationary after first differencing for only Nigeria at the 5\% significance level. However, real GDP is I(1) for Equatorial Guinea at the $10 \%$ level of significance. The results of the unit root tests on the residual (u) of the estimated Equation (1) are also shown in Table 1. The null hypothesis of a unit root at level is rejected for only Equatorial Guinea and Gambia at the 5\% and 10\% levels of significance respectively, thus indicating the existence of cointegration among the variables in those countries only. The variables can therefore be validly represented by error correction mechanisms in Equatorial Guinea and Gambia only.

Table 2 presents the regression estimates of the error correction model for Equatorial Guinea. The results show 
that all the variables except the interest rate, the exchange rate and the exchange rate volatility significantly influence the demand for real money balances in the short run. The short term real GDP carries the correct positive sign. While the short term exchange rate has a positive sign the exchange rate volatility carries a negative sign indicating a greater substitution effect than wealth effect. The short term inflation rate and the interest rate volatility have the wrong positive and negative signs respectively, whilst the short term interest rate carries the correct negative sign. The error correction term is statistically significant and has the correct negative sign. It indicates that agents adjust their money holdings by $14 \%$ quarterly.

Table 2. Results of the error correction model estimates for Equatorial Guinea

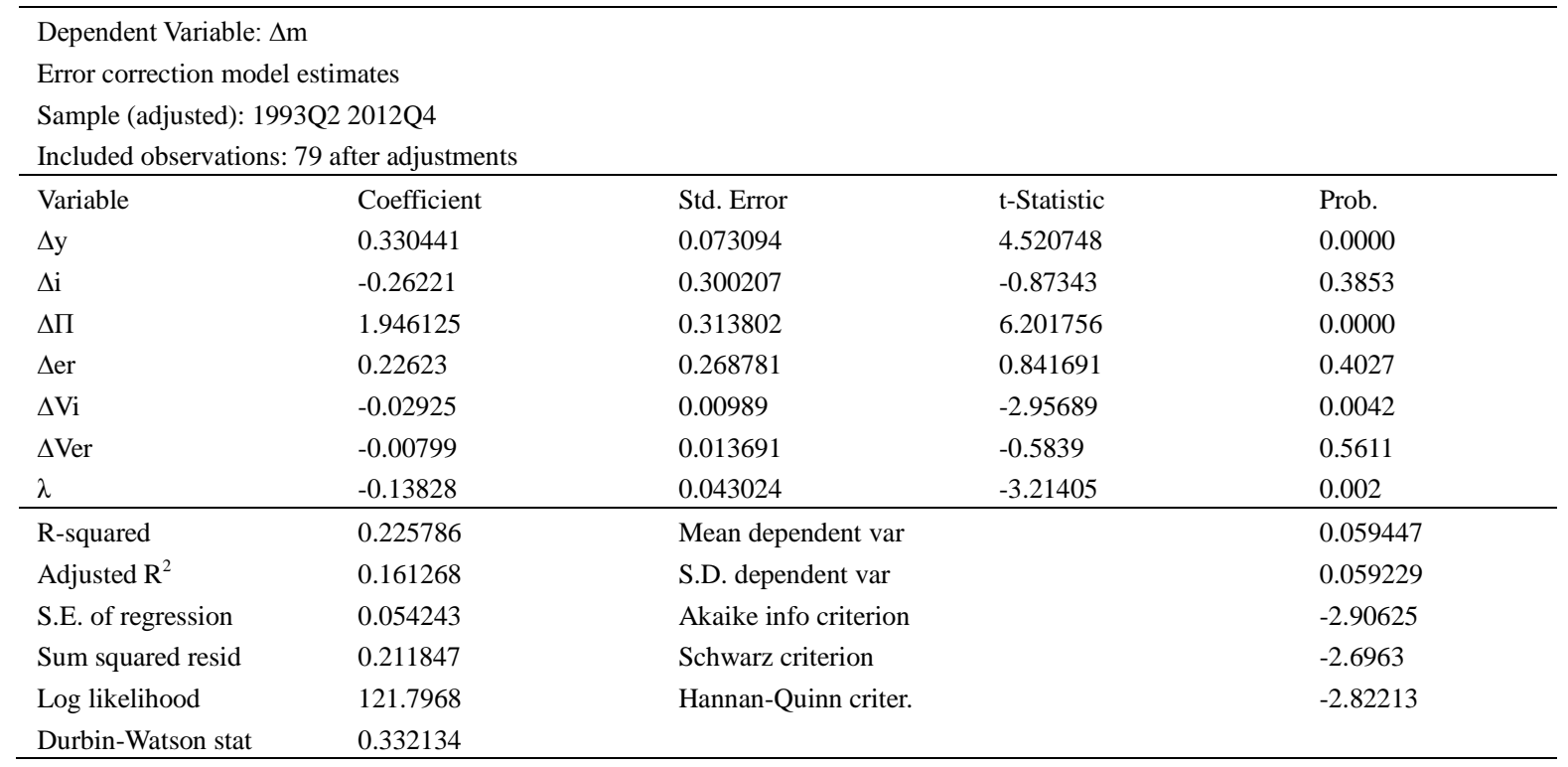

The results for the error correction estimates for Gambia are shown in Table 3. The results show that all the variables except the interest rate, the exchange rate and the inflation rate do not significantly influence the demand for real money balances in the short run. The short term interest rate volatility and real GDP carry the correct positive sign. While the short term exchange rate has a negative sign the exchange rate volatility carries a positive sign indicating the dominance of the wealth effect over the substitution effect. The short term inflation rate has a wrong positive sign whilst the short term interest rate carries the correct negative sign. Even though the error correction term is not statistically significant it has the correct negative sign. It indicates that agents adjust their money holdings by about $3.3 \%$ quarterly.

Table 3. Results of the error correction model estimates for Gambia

\begin{tabular}{|c|c|c|c|c|}
\hline \multicolumn{5}{|c|}{$\begin{array}{l}\text { Dependent Variable: } \Delta \mathrm{m} \\
\text { Error correction model estimates } \\
\text { Sample (adjusted): 1993Q2 2012Q4 } \\
\text { Included observations: } 79 \text { after adjustments }\end{array}$} \\
\hline Variable & Coefficient & Std. Error & t-Statistic & Prob. \\
\hline$\Delta y$ & 0.441691 & 0.430215 & 1.026675 & 0.3080 \\
\hline$\Delta \mathrm{i}$ & -0.29897 & 0.134826 & -2.21744 & 0.0298 \\
\hline$\Delta \Pi$ & 0.827472 & 0.372032 & 2.224194 & 0.0293 \\
\hline$\Delta \mathrm{er}$ & -0.58718 & 0.229451 & -2.55908 & 0.0126 \\
\hline$\Delta \mathrm{Vi}$ & 0.009538 & 0.009469 & 1.007343 & 0.3171 \\
\hline$\Delta$ Ver & 0.008937 & 0.011292 & 0.791457 & 0.4313 \\
\hline$\lambda$ & -0.03257 & 0.045734 & -0.71218 & 0.4787 \\
\hline R-squared & 0.123678 & \multicolumn{2}{|c|}{ Mean dependent var } & 0.022942 \\
\hline Adjusted $\mathrm{R}^{2}$ & 0.050651 & \multicolumn{2}{|c|}{ S.D. dependent var } & 0.039964 \\
\hline S.E. of regression & 0.038939 & \multicolumn{2}{|c|}{ Akaike info criterion } & -3.56922 \\
\hline Sum squared resid & 0.109169 & \multicolumn{2}{|c|}{ Schwarz criterion } & -3.35926 \\
\hline Log likelihood & 147.984 & \multirow{2}{*}{\multicolumn{2}{|c|}{ Hannan-Quinn criter. }} & -3.4851 \\
\hline Durbin-Watson stat & 0.296584 & & & \\
\hline
\end{tabular}


Equation (1) is estimated to obtain regression estimates for the long-run model. The results from EViews are presented in Table 4 below. The long-run coefficient estimates are reported under panel A of table 4 .

The income elasticity is significant in all countries and the interest rate is significant in all countries except Equatorial Guinea, and it has the wrong positive signs for Equatorial Guinea and Nigeria. The inflation rate is also significant in all countries except Gambia and Nigeria at the 5\% level, however, it carries the wrong positive sign for all countries except Gambia. The interest rate volatility is insignificant for all countries and carries the wrong negative sign for Equatorial Guinea contrary to theoretical expectations. The exchange rate volatility is insignificant for all countries except Gambia and has a positive sign in all countries except Uganda. This means that the currency substitution effect outweighs the wealth effect in Uganda whilst the wealth effect is dominant in the other three countries.

Panel B of Table 4 reports some other diagnostics statistics. The F-statistics indicate joint significance of the variables in determining the demand for money for all the countries. The high adjusted R-squares also is an indication of goodness of fit of the model for all countries. The results of the CUSUM and CUSUMSQ tests for the stability of the long-run parameter estimates are also reported in panel B of Table 4 with the results indicating that both tests do not support stability of demand for money for all countries. These two tests for each country are presented graphically in Appendix 1. The plots for the CUSUM and CUSUMSQ tests at certain periods are out of the critical bounds for all the countries.

Table 4. Long-run coefficient estimates

\begin{tabular}{lcccc}
\hline & Equatorial Guinea & Gambia & Uganda & Nigeria \\
\hline Panel A: Long-run estimates & & & & $-9.85(0.00)$ \\
Constant & $-4.00(0.00)$ & $-22.71(0.00)$ & $-3.07(0.57)$ & $1.20(0.00)$ \\
$\mathrm{y}$ & $0.32(0.00)$ & $2.51(0.00)$ & $1.09(0.00)$ & $0.70(0.00)$ \\
$\mathrm{i}$ & $0.01(0.97)$ & $-0.42(0.00)$ & $-0.20(0.00)$ & $0.003(0.96)$ \\
$\Pi$ & $2.06(0.00)$ & $-0.20(0.44)$ & $0.55(0.01)$ & $0.20(0.26)$ \\
$\mathrm{er}$ & $1.77(0.00)$ & $-1.22(0.00)$ & $-0.73(0.00)$ & $0.04(0.31)$ \\
Vi & $-0.01(0.40)$ & $0.01(0.55)$ & $0.01(0.37)$ & $0.04(0.26)$ \\
Ver & $0.01(0.79)$ & $0.07(0.00)$ & $-0.01(0.66)$ & 0.8560 \\
Panel B: Diagnostics & & & & $79.23(0.00)$ \\
Adjusted R-squared & 0.9893 & 0.9750 & 0.9875 & Unstable \\
F-statistics & $1218.60(0.00)$ & $513.68(0.00)$ & $1042.66(0.00)$ & Unstable \\
CUSUM & Unstable & Unstable & Unstable & Unstable \\
CUSUMSQ & Unstable & Unstable & \multicolumn{2}{c}{. }
\end{tabular}

Note. The probability values are shown in parentheses next to each coefficient estimate. CUSUM (the cumulative sum of recursive residuals) and CUSUMSQ (the cumulative sum of squares of recursive residuals) are the tests for the stability of all coefficient estimates of equation (1).

\subsection{Robustness Analysis}

The robustness of the baseline results to the alternative model specified by equation (7) is assessed in this section. Table 5 reports the short-run coefficient estimates and Table 6 the long-run estimates and other diagnostic statistics. The optimum lag structure obtained is eight lags. The short-run results in Table 5 show that for Equatorial Guinea there is at least one lagged coefficient that is significant at the 5\% or $10 \%$ level. However, for Gambia, virtually all variables are insignificant with the exception of the lag eight variable of the interest rate volatility which is significant at the $10 \%$ level. The baseline results indicate that for Equatorial Guinea all the variables except the interest rate, the exchange rate and the exchange rate volatility significantly influence the demand for real money balances in the short run while for Gambia all the variables except the interest rate, the exchange rate and the inflation rate do not significantly influence the demand for real money balances in the short run. The alternative results relating to the variables of interest (the interest rate volatility and the exchange rate volatility) appear to be inconsistent in the case of Equatorial Guinea and consistent in the case of Gambia with the baseline specification in the short run. The exchange rate and interest rate volatilities are statistically insignificant for Gambia for both models but show conflicting results for the two models in the case of Equatorial Guinea. Cointegration must be established among the variables in order to validly interpret the long run coefficient estimates. When it comes to the establishment of cointegration the alternative results are quite consistent with the baseline results. While the baseline results report cointegration among the variables for only Equatorial Guinea and Gambia the alternative specification indicates cointegration for Uganda in addition to the 
two countries. The F statistic reported under panel B in Table 6 is greater than its upper bound critical value of 3.61 in all the countries except Nigeria. Even though the lagged error correction term carries the expected negative coefficient for Nigeria it is statistically insignificant. One can validly interpret the long-run coefficient estimates reported under panel A of Table 6 for only Equatorial Guinea, Gambia and Uganda. The results relating to the interest rate volatility and the exchange rate volatility are inconsistent with the baseline results in the long run. However, majority of the results for both models indicate that these variables are not statistically significant implying that volatilities in the interest rate and the exchange rate do not influence the demand for money to any great extent in developing countries. The findings are not robust as far as the results of the CUSUM and CUSUMSQ tests for stability are concerned. The alternative results indicate stability of the money demand for developing countries while the baseline results show instability in the money demand functions. (See Appendix).

Table 5a. Short-run coefficient estimates

\begin{tabular}{|c|c|c|c|c|}
\hline & Equatorial Guinea & Gambia & Uganda & Nigeria \\
\hline \multicolumn{5}{|c|}{ Short-run estimates } \\
\hline$\Delta \mathrm{m}_{\mathrm{t}-1}$ & $0.64(0.005)$ & $0.46(0.54)$ & $-0.13(0.91)$ & $-0.10(0.91)$ \\
\hline$\Delta \mathrm{m}_{\mathrm{t}-2}$ & $0.71(0.01)$ & $0.24(0.86)$ & $-1.45(0.19)$ & $-0.29(0.66)$ \\
\hline$\Delta \mathrm{m}_{\mathrm{t}-3}$ & $0.91(0.01)$ & $-0.38(0.61)$ & $0.57(0.38)$ & $1.19(0.13)$ \\
\hline$\Delta \mathrm{m}_{\mathrm{t}-4}$ & $0.32(0.12)$ & $-0.82(0.45)$ & $-1.86(0.12)$ & $-0.84(0.53)$ \\
\hline$\Delta \mathrm{m}_{\mathrm{t}-5}$ & $0.39(0.05)$ & $-0.56(0.22)$ & $0.09(0.89)$ & $-0.73(0.45)$ \\
\hline$\Delta \mathrm{m}_{\mathrm{t}-6}$ & $0.31(0.10)$ & $0.02(0.98)$ & $-0.81(0.37)$ & $0.67(0.39)$ \\
\hline$\Delta \mathrm{m}_{\mathrm{t}-7}$ & $1.03(0.004)$ & $0.07(0.90)$ & $0.50(0.37)$ & $-0.67(0.39)$ \\
\hline$\Delta \mathrm{m}_{\mathrm{t}-8}$ & $-0.83(0.008)$ & $0.51(0.58)$ & $0.67(0.36)$ & $-0.59(0.43)$ \\
\hline$\Delta \mathrm{y}_{\mathrm{t}}$ & $0.10(0.08)$ & $4.95(0.29)$ & $-1.17(0.61)$ & $0.15(0.67)$ \\
\hline$\Delta \mathrm{y}_{\mathrm{t}-1}$ & $-0.09(0.31)$ & $-1.65(0.72)$ & $3.97(0.33)$ & $-0.52(0.24)$ \\
\hline$\Delta \mathrm{y}_{\mathrm{t}-2}$ & $-0.20(0.04)$ & $0.88(0.86)$ & $-2.68(0.19)$ & $0.47(0.45)$ \\
\hline$\Delta \mathrm{y}_{\mathrm{t}-3}$ & $-0.36(0.03)$ & $-0.50(0.83)$ & $1.05(0.60)$ & $0.16(0.56)$ \\
\hline$\Delta \mathrm{y}_{\mathrm{t}-4}$ & $0.24(0.03)$ & $3.16(0.51)$ & $2.67(0.17)$ & $0.18(0.44)$ \\
\hline$\Delta \mathrm{y}_{\mathrm{t}-5}$ & $-0.14(0.07)$ & $-0.18(0.89)$ & $1.38(0.28)$ & $-0.09(0.62)$ \\
\hline$\Delta \mathrm{y}_{\mathrm{t}-6}$ & $-0.14(0.03)$ & $-0.66(0.75)$ & $-0.56(0.52)$ & $-0.001(0.99)$ \\
\hline$\Delta \mathrm{y}_{\mathrm{t}-7}$ & $-0.13(0.05)$ & $-1.19(0.64)$ & $0.54(0.35)$ & $0.25(0.15)$ \\
\hline$\Delta \mathrm{y}_{\mathrm{t}-8}$ & $0.28(0.004)$ & $5.38(0.23)$ & $1.87(0.28)$ & $0.38(0.29)$ \\
\hline$\Delta \mathrm{i}_{\mathrm{t}}$ & $2.55(0.02)$ & $0.53(0.80)$ & $0.10(0.27)$ & $0.02(0.89)$ \\
\hline$\Delta \mathrm{i}_{\mathrm{t}-1}$ & $-0.19(0.74)$ & $0.30(0.74)$ & $-0.10(0.59)$ & $-0.08(0.80)$ \\
\hline$\Delta \mathrm{i}_{\mathrm{t}-2}$ & $-0.52(0.23)$ & $-0.27(0.91)$ & $0.02(0.87)$ & $-0.23(0.31)$ \\
\hline$\Delta \mathrm{i}_{\mathrm{t}-3}$ & $1.20(0.03)$ & $0.83(0.66)$ & $-0.03(0.79)$ & $-0.07(0.76)$ \\
\hline$\Delta \mathrm{i}_{\mathrm{t}-4}$ & $-1.85(0.01)$ & $-2.22(0.23)$ & $0.27(0.34)$ & $0.06(0.82)$ \\
\hline$\Delta \mathrm{i}_{\mathrm{t}-5}$ & $-1.11(0.01)$ & $0.31(0.85)$ & $-0.20(0.10)$ & $-0.01(0.98)$ \\
\hline$\Delta \mathrm{i}_{\mathrm{t}-6}$ & $-0.96(0.04)$ & $-0.05(0.96)$ & $-0.004(0.96)$ & $-0.24(0.31)$ \\
\hline$\Delta \mathrm{i}_{\mathrm{t}-7}$ & $-0.19(0.34)$ & $-0.39(0.83)$ & $-0.18(0.06)$ & $-0.09(0.75)$ \\
\hline$\Delta \mathrm{i}_{\mathrm{t}-8}$ & $-1.33(0.01)$ & $1.19(0.50)$ & $-0.16(0.12)$ & $0.15(0.57)$ \\
\hline$\Delta \Pi_{\mathrm{t}}$ & $5.98(0.09)$ & $12.55(0.17)$ & $-8.39(0.09)$ & $-0.52(0.54)$ \\
\hline$\Delta \Pi_{\mathrm{t}-1}$ & $-0.95(0.53)$ & $-3.29(0.60)$ & $4.18(0.07)$ & $0.01(0.99)$ \\
\hline$\Delta \Pi_{\mathrm{t}-2}$ & $-0.82(0.46)$ & $-6.39(0.13)$ & $-5.21(0.12)$ & $0.34(0.73)$ \\
\hline$\Delta \Pi_{\mathrm{t}-3}$ & $3.93(0.03)$ & $4.62(0.52)$ & $3.45(0.21)$ & $-1.72(0.19)$ \\
\hline$\Delta \Pi_{\mathrm{t}-4}$ & $3.78(0.23)$ & $9.97(0.14)$ & $-9.30(0.06)$ & $-1.50(0.54)$ \\
\hline$\Delta \Pi_{\mathrm{t}-5}$ & $-0.03(0.98)$ & $6.54(0.20)$ & $1.37(0.56)$ & $-0.59(0.74)$ \\
\hline$\Delta \Pi_{\mathrm{t}-6}$ & $-1.24(0.43)$ & $-7.49(0.34)$ & $-0.47(0.72)$ & $2.09(0.23)$ \\
\hline$\Delta \Pi_{\mathrm{t}-7}$ & $6.26(0.02)$ & $-2.96(0.83)$ & $4.72(0.09)$ & $0.97(0.58)$ \\
\hline$\Delta \Pi_{\mathrm{t}-8}$ & $-3.45(0.03)$ & $8.37(0.20)$ & $-3.16(0.35)$ & $-2.82(0.17)$ \\
\hline
\end{tabular}

Note. The absolute value of the $t$-ratio is shown in brackets. 
Table 5b. Short-run coefficient estimates

\begin{tabular}{|c|c|c|c|c|}
\hline & Equatorial Guinea & Gambia & Uganda & Nigeria \\
\hline \multicolumn{5}{|c|}{ Short-run estimates } \\
\hline$\Delta \mathrm{er}_{\mathrm{t}}$ & $-2.19(0.06)$ & $3.10(0.37)$ & $-2.67(0.26)$ & $-0.08(0.63)$ \\
\hline$\Delta \mathrm{er}_{\mathrm{t}-1}$ & $-0.23(0.74)$ & $-1.50(0.61)$ & $1.78(0.27)$ & $0.23(0.50)$ \\
\hline$\Delta \mathrm{er}_{\mathrm{t}-2}$ & $-2.01(0.01)$ & $0.54(0.74)$ & $-1.02(0.38)$ & $-0.25(0.43)$ \\
\hline$\Delta \mathrm{er}_{\mathrm{t}-3}$ & $-3.31(0.01)$ & $-0.60(0.91)$ & $3.52(0.13)$ & $0.55(0.35)$ \\
\hline$\Delta \mathrm{er}_{\mathrm{t}-4}$ & $0.63(0.17)$ & $-0.22(0.90)$ & $-2.91(0.10)$ & $-0.09(0.70)$ \\
\hline$\Delta \mathrm{er}_{\mathrm{t}-5}$ & $-0.52(0.24)$ & $-1.69(0.57)$ & $1.13(0.38)$ & $0.35(0.26)$ \\
\hline$\Delta \mathrm{er}_{\mathrm{t}-6}$ & $-0.67(0.03)$ & $0.30(0.87)$ & $-1.85(0.09)$ & $-0.16(0.65)$ \\
\hline$\Delta \mathrm{er}_{\mathrm{t}-7}$ & $-1.55(0.01)$ & $1.00(0.62)$ & $1.30(0.20)$ & $1.04(0.17)$ \\
\hline$\Delta \mathrm{er}_{\mathrm{t}-8}$ & $1.21(0.03)$ & $-0.82(0.63)$ & $-0.71(0.31)$ & $-0.05(0.92)$ \\
\hline$\Delta \mathrm{Vi}_{\mathrm{t}}$ & $-0.002(0.02)$ & $-0.00(0.98)$ & $-0.005(0.05)$ & $-0.01(0.19)$ \\
\hline$\Delta \mathrm{Vi}_{\mathrm{t}-1}$ & $0.02(2.09)$ & $-0.03(0.60)$ & $0.05(0.47)$ & $0.04(0.34)$ \\
\hline$\Delta \mathrm{Vi}_{\mathrm{t}-2}$ & $0.01(0.33)$ & $-0.04(0.52)$ & $0.04(0.52)$ & $0.02(0.58)$ \\
\hline$\Delta \mathrm{Vi}_{\mathrm{t}-3}$ & $0.01(0.53)$ & $-0.05(0.48)$ & $0.02(0.60)$ & $0.01(0.71)$ \\
\hline$\Delta \mathrm{Vi}_{\mathrm{t}-4}$ & $0.003(0.67)$ & $-0.05(0.42)$ & $0.01(0.68)$ & $0.01(0.78)$ \\
\hline$\Delta \mathrm{Vi}_{\mathrm{t}-5}$ & $0.003(0.59)$ & $-0.06(0.32)$ & $0.01(0.79)$ & $0.002(0.92)$ \\
\hline$\Delta \mathrm{Vi}_{\mathrm{t}-6}$ & $0.003(0.46)$ & $-0.04(0.29)$ & $-0.00(0.98)$ & $-0.004(0.69)$ \\
\hline$\Delta \mathrm{Vi}_{\mathrm{t}-7}$ & $0.001(0.37)$ & $-0.02(0.24)$ & $-0.001(0.91)$ & $-0.005(0.25)$ \\
\hline$\Delta \mathrm{Vi}_{\mathrm{t}-8}$ & $0.0002(0.76)$ & $-0.01(0.10)$ & $-0.001(0.81)$ & $-0.002(0.53)$ \\
\hline$\Delta \operatorname{Ver}_{\mathrm{t}}$ & $0.004(0.01)$ & $-0.01(0.74)$ & $0.01(0.07)$ & $0.01(0.05)$ \\
\hline$\Delta \operatorname{Ver}_{\mathrm{t}-1}$ & $-0.05(0.004)$ & $0.06(0.81)$ & $-0.03(0.42)$ & $-0.09(0.22)$ \\
\hline$\Delta \operatorname{Ver}_{\mathrm{t}-2}$ & $-0.04(0.01)$ & $0.05(0.80)$ & $-0.04(0.37)$ & $-0.06(0.28)$ \\
\hline$\Delta \operatorname{Ver}_{\mathrm{t}-3}$ & $-0.02(0.01)$ & $0.03(0.82)$ & $-0.04(0.31)$ & $-0.04(0.38)$ \\
\hline$\Delta \operatorname{Ver}_{\mathrm{t}-4}$ & $-0.01(0.02)$ & $0.01(0.91)$ & $-0.04(0.30)$ & $-0.03(0.34)$ \\
\hline$\Delta \operatorname{Ver}_{\mathrm{t}-5}$ & $-0.01(0.10)$ & $-0.02(0.54)$ & $-0.03(0.31)$ & $-0.03(0.30)$ \\
\hline$\Delta \operatorname{Ver}_{\mathrm{t}-6}$ & $-0.003(0.33)$ & $-0.03(0.19)$ & $-0.02(0.32)$ & $-0.02(0.42)$ \\
\hline$\Delta \operatorname{Ver}_{\mathrm{t}-7}$ & $-0.002(0.25)$ & $-0.02(0.22)$ & $-0.01(0.42)$ & $-0.01(0.41)$ \\
\hline$\Delta \operatorname{Ver}_{\mathrm{t}-8}$ & $-0.000(0.92)$ & $-0.01(0.17)$ & $-0.003(0.39)$ & $-0.002(0.82)$ \\
\hline
\end{tabular}

Note. The absolute value of the $t$-ratio is shown in brackets.

Table 6. Long-run coefficient estimates

\begin{tabular}{lcccc}
\hline & Equatorial Guinea & Gambia & Uganda & Nigeria \\
\hline Panel A: Long-run estimates & & & & \\
Constant & $-1.25(0.003)$ & $0.48(0.77)$ & $0.78(0.33)$ & $0.08(0.79)$ \\
$\mathrm{y}$ & $0.64(0.002)$ & $1.81(0.67)$ & $-1.59(0.54)$ & $0.07(0.91)$ \\
$\mathrm{i}$ & $-0.67(0.02)$ & $-0.17(0.93)$ & $0.16(0.48)$ & $0.29(0.53)$ \\
$\Pi$ & $1.89(0.03)$ & $-0.99(0.34)$ & $0.56(0.69)$ & $-0.05(0.83)$ \\
$\mathrm{er}$ & $1.91(0.005)$ & $1.32(0.49)$ & $0.21(0.65)$ & $-0.02(0.93)$ \\
$\mathrm{Vi}$ & $-0.03(0.09)$ & $0.03(0.59)$ & $-0.06(0.40)$ & $-0.06(0.20)$ \\
Ver & $0.06(0.003)$ & $-0.07(0.81)$ & $0.02(0.63)$ & $0.12(0.15)$ \\
Panel B: Diagnostics & & & & \\
Wald Test (F-statistics) & 37.99 & 6.87 & 32.81 & 1.19 \\
ECM & $-0.11(0.25)$ & $-2.32(0.10)$ & $-1.38(0.69)$ & $-0.63(0.41)$ \\
LM & 71.49 & 72.88 & 69.88 & 71.92 \\
CUSUM & Stable & Stable & Stable & Unstable \\
CUSUMSQ & Stable & Unstable & Stable & Stable \\
\hline
\end{tabular}

Note. The probability values are shown in parentheses next to each coefficient estimate. The Lagrange multiplier (LM) test of residual serial correlation has a $\chi^{2}$ distribution with two degrees of freedom. CUSUM and CUSUMSQ are the tests for the stability of all coefficient estimates of equation (7). The critical value of the F-statistic for upper bound and the lower bound with six regressors are 3.61 and 2.45 respectively, at the 5\% level of significance. See Pesaran et al. (2001, Table CI (iii): Case III, p. 300).

\section{Conclusion}

The right opportunity cost variable to enter the money demand function and the stability of the function are the 
main issues which have been investigated by researchers concerning the demand for money. The level of economic activity and the rate of interest are often considered the main factors that determine the demand for money in a country. Fleming (1962) identified the exchange rate as one of the key determinants of money demand for an open economy in addition to income and the interest rate. Uncertainty or volatility in exchange rates could have an effect on the amount of cash balances being held by agents. An adverse exchange rate, in the form of volatility will cause economic agents to substitute the domestic currency for foreign currency, thus reducing the demand for money balances. Economic theory shows that interest rate volatility also increases the demand for money. Interest rate and exchange rate volatilities or uncertainties could cause money demand functions to be unstable. The stability of money demand functions has implications for the choice of monetary policy instruments.

Despite the fact that interest rate and exchange rate volatilities could trigger instability in the money demand functions, these issues have been seldom investigated in developing economies relative to the advanced ones. Besides, most studies have had as their main objective to either examine the effect of the interest rate volatility or the exchange rate volatility but not the effects of both simultaneously. Consequently, this study investigates the stability of money demand and the effects of interest and exchange rates volatilities on the demand for money in developing economies using time series data of four African countries namely, Equatorial Guinea, Gambia, Nigeria and Uganda. The model used is a conventional log linear money demand function, with money demand specified as a function of income, interest rate, inflation rate, exchange rate, interest rate volatility and exchange rate volatility. It is found that on the whole the interest rate and exchange rate volatilities do not have significant effects on the demand for money in developing countries and the money demand functions for these countries are unstable. The policy implication is that Central banks of these economies should resort to inflation targeting monetary policy using the interest rate as the policy instrument. This study therefore contributes to a great extent to the debate on which appropriate monetary policy to pursue in developing economies. However, the results are not robust and consistent with those of the bound testing approach with an alternative model specification. It is therefore recommended that further studies should be conducted using a panel data of developing countries.

\section{References}

Arestis, \& Demetriades, P. O. (1991, September). Cointegration, Error Correction and the Demand for Money in Cyprus. Applied Economics, 23(9), 1417-24. https://doi.org/10.1080/00036849100000192

Benassy-Quere, A., \& Coupet, M. (2005). On the Adequacy of Monetary Arrangements in Sub-Saharan Africa. World Economy, 28, 349- 373. https://doi.org/10.1111/j.1467-9701.2005.00649.x

Celikoz, Y. K., \& Arslan, U. (2011, October). The effects of the interest rate volatility on Turkish money demand. International Business Research, 4(4), 286-297. https://doi.org/10.5539/ibr.v4n4p286

Dehmardeh, N., \& Izadi, H. (2009). Analyzing the Money Demand function in Iran. Economic Research Review, (33), 153-.170.

Engle, R. F., \& Granger, C. W. J. (1987). Cointegration and Error Correction: Representation, Estimation, and Testing. Econometrica, 55, 51-276. https://doi.org/10.2307/1913236

Fleming, J. M. (1962, November). Domestic Financial Policies under Fixed and Floating Exchange Rates. IMF Staff Papers, 9, 369-379. https://doi.org/10.2307/3866091

Gaurisankar, S., \& Kwie-Jurgens, N. (2013). The Money Demand Function in Suriname. Journal of Business, Finance \& Economics in Emerging Economies, 8(2), 1-25.

Githinji, A. N. (2015). The Effect of Interest Rate Volatility on Money Demand in Kenya. A Master of Arts Dissertation in Economics, School of Economics, University of Nairobi.

Izadi, H. R., \& Dehmardeh, N. (2012). The Relationship between Money Demand Function, Performance of Monetary and Financial Policies and Forecasting the Money Demand Function in Iran. Quarterly Journal of Applied Economics Studies in Iran, 1(1), 165-190.

McKinnon, R. I. (1996). Direct and Indirect Concepts of International Currency Substitution. In P. Mizen, \& E. J. Pentecost (Eds.), The Macroeconomics of International Currencies. Aldershot, Edward Elgar.

Miles, M. A. (1978). Currency Substitution, Flexible Exchange Rates and Monetary Independence. American Economic Review, 428, 36-68.

Mundell, A. R. (1963). Capital Mobility and Stabilization Policy under Fixed and Flexible Exchange Rates. Canadian Journal of Economics and Political Science, 29(4), 475-85. https://doi.org/10.2307/139336 
Pesaran, H. M., Shin, Y., \& Smith, R. J. (2001). Bounds Testing Approaches to the Analysis of Level Relationships. Journal of Applied Econometrics, 16, 289-326. https://doi.org/10.1002/jae.616

Poole, W. (1970). The optimal choice of monetary policy instruments in a simple macro model. Quarterly Journal of Economics, 84, 192-216. https://doi.org/10.2307/1883009

Qasim, M., Ahmad, K., \& Chani, M. I. (2015). Exchange Rate Volatility and Money Demand: An Empirical Analysis of Pakistan. Journal of Policy Research, 1(3), 131-141.

Sahar, B. (2013). Exchange rate volatility and demand for money in less developed countries. Journal of Economics and Finance, 37(3), 171-176. https://doi.org/10.1007/s12197-011-9190-y

Sameti, M., \& Mehdi, Y. (2011). Econometric Analysis of monetary Demand in Iran. Iranian Economic Journal: Macroeconomics (IEJM), 39(10), 99-122.

\section{Appendix 1. The CUSUM and CUSUMSQ Stability Tests on Money Demand Coefficients}

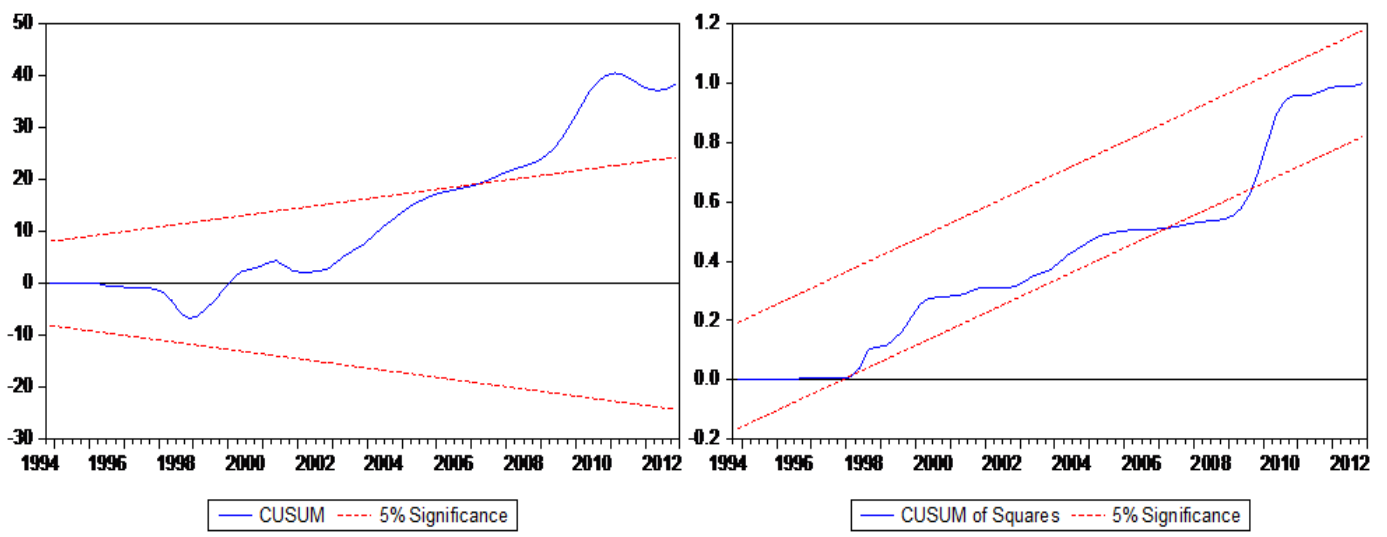

Figure A1. Stability test for Equatorial Guinea
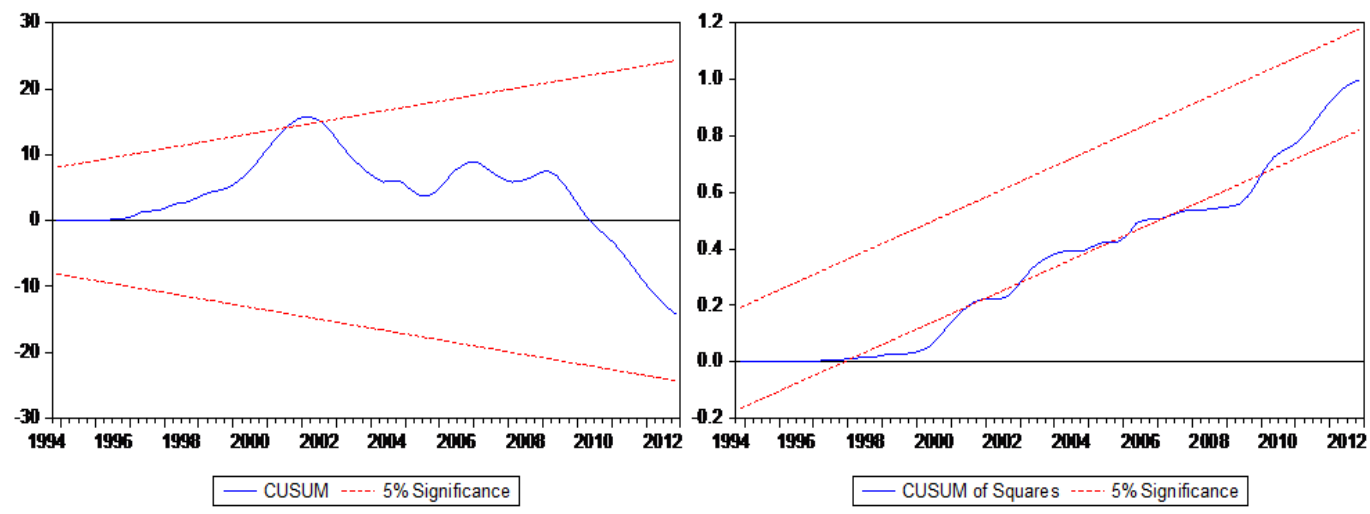

Figure A2. Stability test for Gambia

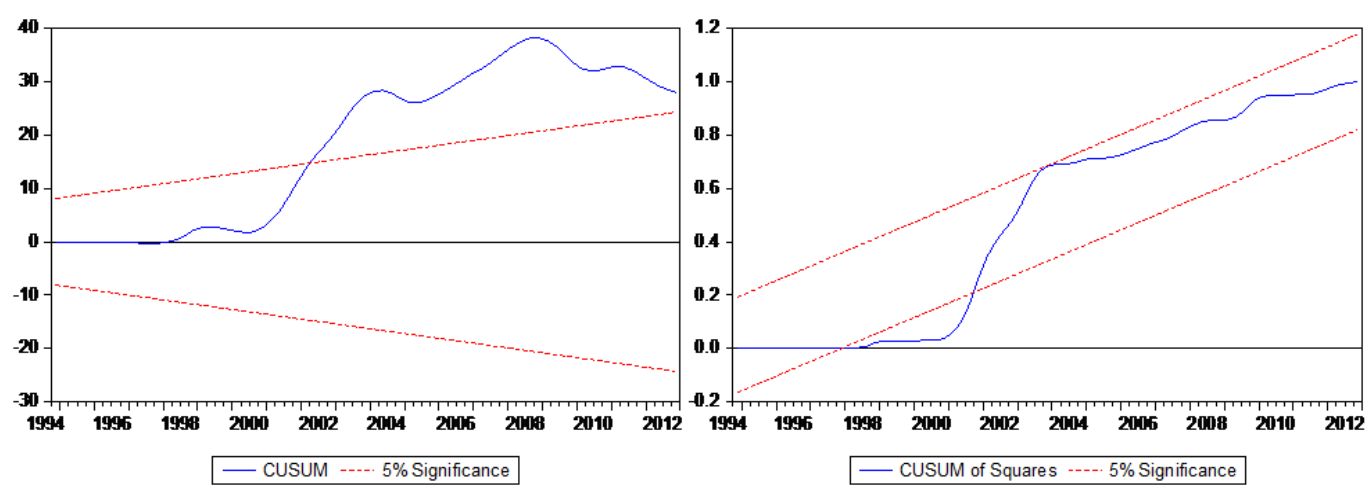

Figure A3. Stability test for Uganda 


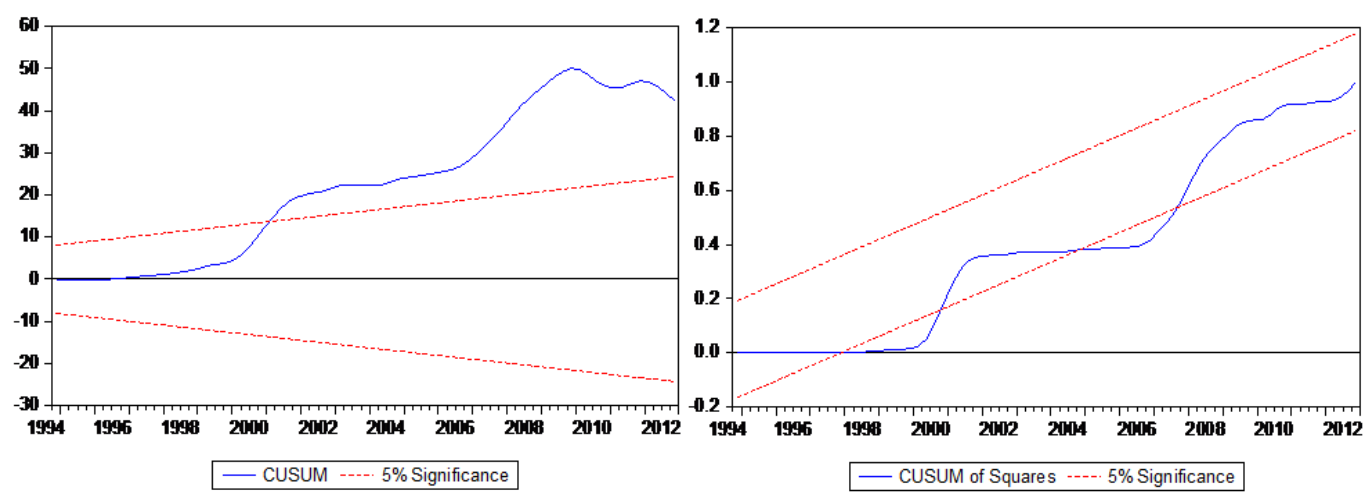

Figure A4. Stability test for Nigeria

\section{Appendix 2. The CUSUM and CUSUMSQ Stability Tests on Money Demand Coefficients}
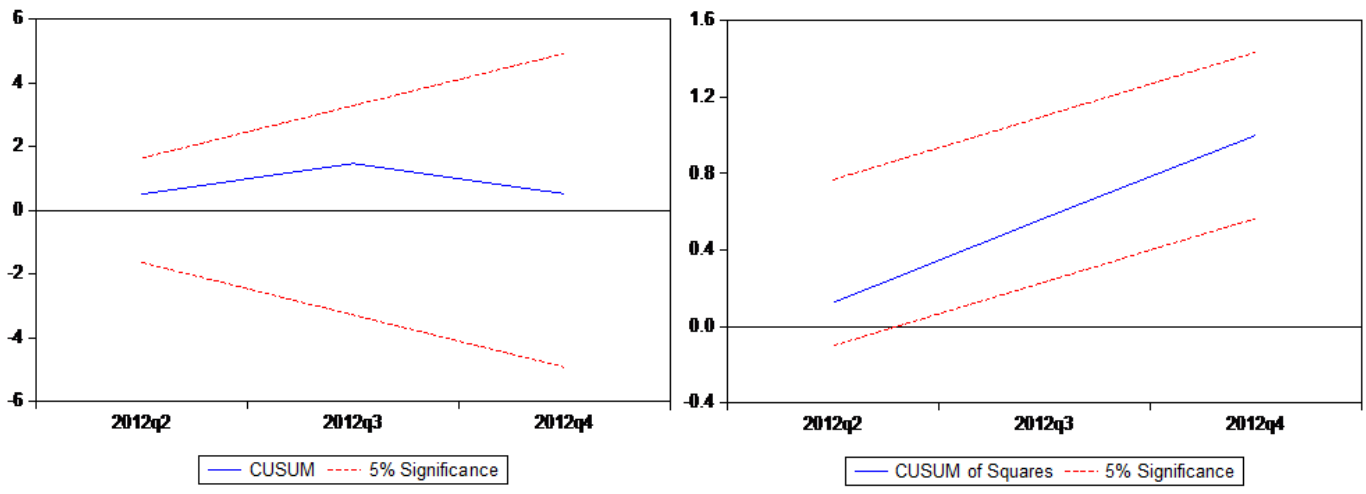

Figure B1. Stability test for Equatorial Guinea
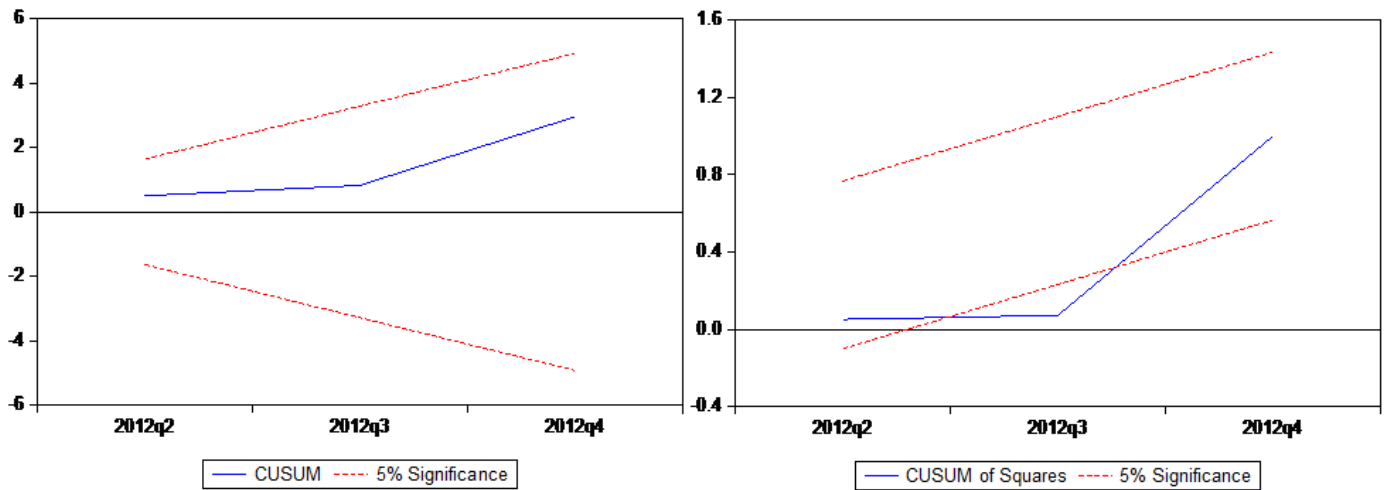

Figure B2. Stability test for Gambia
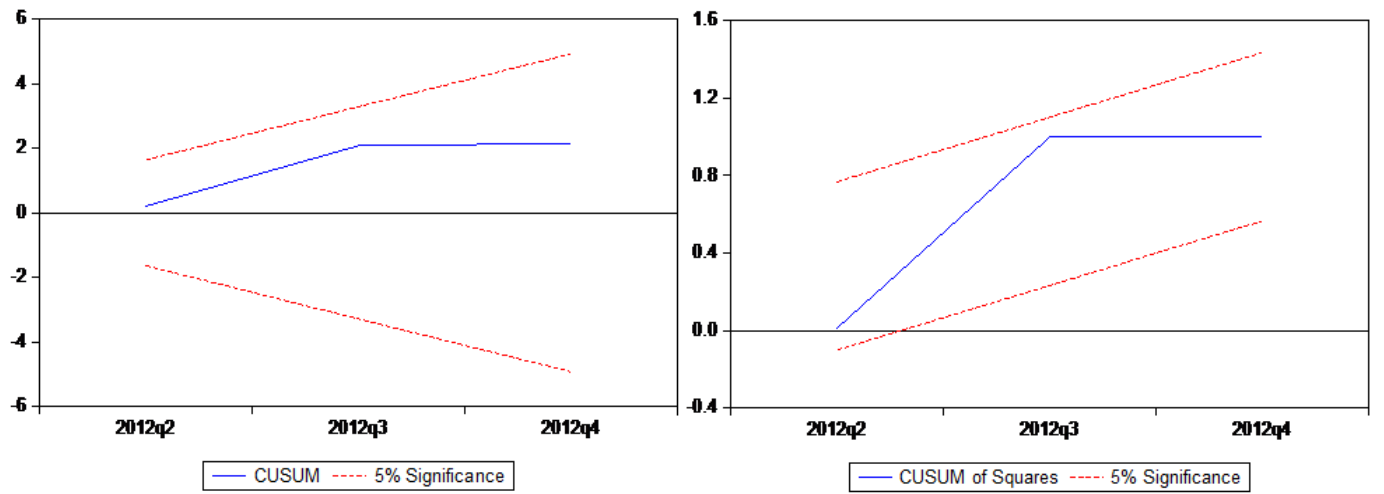

Figure B3. Stability test for Uganda 

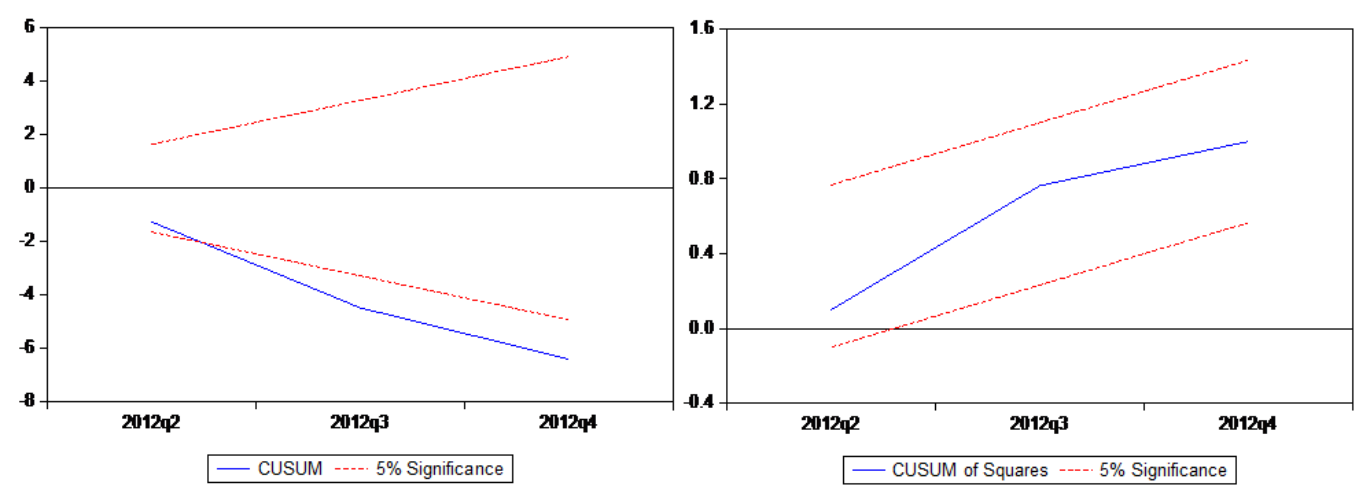

Figure B4. Stability test for Nigeria

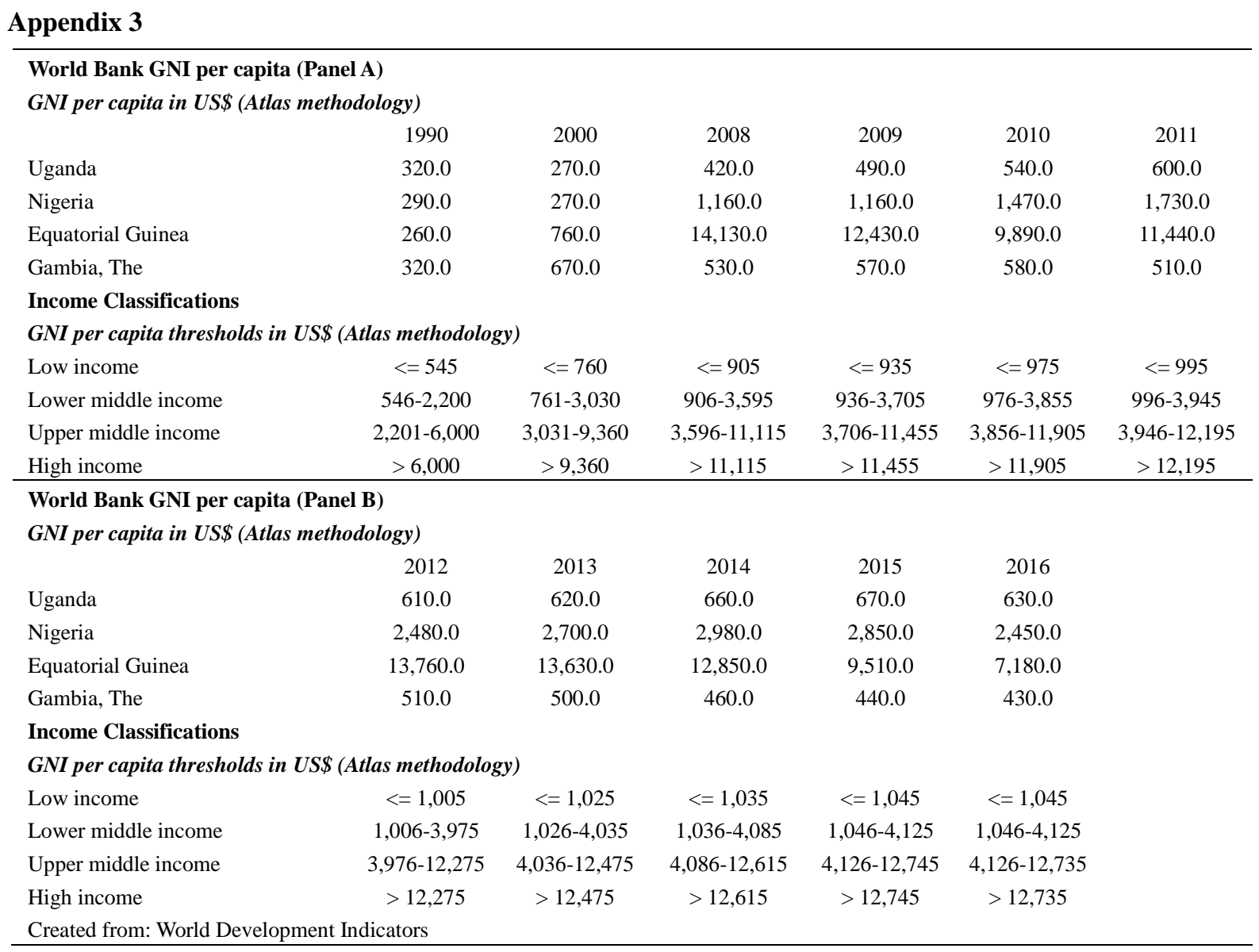

\section{Copyrights}

Copyright for this article is retained by the author(s), with first publication rights granted to the journal.

This is an open-access article distributed under the terms and conditions of the Creative Commons Attribution license (http://creativecommons.org/licenses/by/4.0/). 